\title{
INTERNAL FORCES ANALYSIS OF CAST-IN-SITU CONCRETE HOLLOW FLOOR BASED ON FINITE ELEMENT ANALYSIS
}

\author{
Kunquan $\mathrm{Li}^{1}$, Rui Wen ${ }^{2}$ \\ ${ }^{1,2}$ Henan University of Engineering, Henan, China \\ Email: wenruiruiwen01@126.com
}

\begin{abstract}
To study and analyze the mechanical property of cast-in-situ concrete light pipe column wallboard, the small deflection theory of thin board was used, aiming to deduce the deflection and internal force expression of cast-in-situ concrete light pipe column wallboard under action of the triangular load and uniform load. The wallboard used the form of three simply supported and one fixed edges. Finally, a table of related coefficients of deflection and internal forces was formed. The ABAQUS finite element analysis software was used to analyze the influence of the factors such as volume hollow ratio, pipe length, load form, boundary condition, axial compression ratio and its action position on the bearing capacity of cast-in-situ concrete light pipe column wallboard. The calculation result showed that the loading capacity of PVC pipe with the length of $1500 \mathrm{~mm}$ was close to one with the length of $1000 \mathrm{~mm}$. When the length of PVC pipe was between $1000 \mathrm{~mm}$ and $1500 \mathrm{~mm}$, the bearing capacity of the wallboard was hardly affected by the length of the PVC pipe. It is concluded that the PVC pipe with a longer length can be selected to effectively reduce the influence of hydration heat of the concrete.
\end{abstract}

Keywords: Cast-in-place concrete; Light pipe column wallboard; Stress performance; Nonlinear; Finite element analysis.

\section{Introduction}

With the acceleration of urbanization, a large number of people are pouring into cities. Therefore, urban living space, traffic congestion and construction land become more and more nervous. To meet the unforeseen disaster and parking need, many high-rise buildings have set up basements.

For high-rise buildings, the internal force and displacement caused by horizontal load rapidly increase due to the increase of building layers.

Therefore, the foundation of high-rise buildings is buried deeply. On the one hand, the stability of the foundation can be ensured, preventing overturning and slippage and reducing the overall inclination of the building. On the other hand, this depth can be fully used to build the basement. The basement is used for the equipment room, underground fire pit and car parking spaces. Its economic effect and the use result are good. Therefore, the basement structure design is an important part of the structural design of high-rise buildings [1].

Because of the length and height of the exterior wall of the basement, the larger shrinkage stress will be produced. Moreover, the concrete used in the exterior wall of the basement is usually the pumping concrete with high strength and high permeability.

Therefore, the construction of cement hydration heat is still relatively large. The thermal conductivity of concrete is relatively poor, and the hydration heat of the internal concrete is not easily lost. Therefore, it is easy to cause large temperature difference between the inside and outside of the concrete. It is very difficult to maintain the vertical plane of the wallboard [2].Some effective methods used to control concrete cracks, such as the heat storage method, cannot be applied to the exterior wall of the basement. All these aggravate the plastic shrinkage deformation of the concrete. With the effect of external force and restraint, cracks are easily produced in the exterior wall of the basement. The cracks in the concrete wall of the basement are a common phenomenon in the engineering practice.

The development of the cracks will lead to the seepage of the groundwater, which has a great influence on the use and safety of the buildings.

From the cause of the crack, people have come up with many methods to control the cracks [3]. The measures to deal with concrete cracks are as follows: It is necessary to choose cement with small water requirement and smaller shrinkage ratio. The sand and stone materials with good particle size gradation are adopted, and high performance admixtures are added. In the construction, stratified pouring and stratified vibration are carried out. After stripping, the sack or bag needs to hang on the wall, and someone is sent to water to maintain the concrete wall. Some structural steel bars with smaller diameter are arranged and concrete post placement measures are set up. The practice shows that 
although these methods can not cure this malpractice, it also effectively controls the development of cracks. From the angle of controlling the crack and drawing on the hollow floor technology, the cast-in-place concrete light pipe column wall panel is formed by the pre-buried hollow pipe in the exterior wall of basement.

It is used to solve the crack problem caused by the thermal stress of the exterior wall of the basement [4].

\section{Flexural Differential Equation of the Cast-in-place Concrete Light Pipe Column Wallboard}

Due to the hollow tube embedded in the exterior wall od basement, the wallboard section stiffness of parallel slabs and perpendicular slabs is different, which results in the orthotropic characteristics of the wallboard. The differences in the stiffness of the two directions will lead to the difference in the calculation of wallboard deflection and internal force distribution.

In this chapter, the deflection and internal force of cast-in-situ concrete lightweight wallboard with three edges simply supported and one side fixed under the action of triangle load and uniformly distributed load are calculated and analyzed by using the small deflection theory of elastic thin plate [5].

Assuming that the wall is subjected to lateral loading, the six basic equilibrium equations can be reduced to the following three.

$$
\sum M_{x}=0, \sum M_{y}=0, \sum P_{Z}=0
$$

The middle surface of the plate unit is subjected to force analysis, and the centre of the middle surface is taken in the direction of $\mathrm{X}$ and $\mathrm{Y}$, respectively.

$$
\left\{\begin{array}{l}
\frac{\partial m_{x}}{\partial x}+\frac{\partial m_{y x}}{\partial y}=q_{x} \\
\frac{\partial m_{y}}{\partial y}+\frac{\partial m_{x y}}{\partial x}=q_{y}
\end{array}\right.
$$

The equilibrium equation of all forces in the direction of $\mathrm{Z}$ is:

$$
\left(q_{x}+\frac{\partial q_{x}}{\partial x} d x\right) d y+\left(q_{y}+\frac{\partial q_{y}}{\partial y} d y\right) d x-q_{x} d y-q_{y} d x+p_{z} d x d y=0
$$

According to $\mathrm{m}_{\mathrm{xy}}=\mathrm{m}_{\mathrm{yx}}$, the following equation is obtained:

$$
\frac{\partial^{2} m_{x}}{\partial x^{2}}+2 \frac{\partial^{2} m_{x y}}{\partial x \partial y}+\frac{\partial^{2} m_{y}}{\partial y^{2}}=-p_{z}(x, y)
$$

\section{Finite Element Nonlinear Analysis of Cast-in-place Concrete Lightweight Pipe Column Wallboard}

\subsection{Finite element nonlinear analysis of cast- in-place concrete lightweight pipe column wallboard}

In this paper, the ABAQUS software is used to make the nonlinear analysis of the cast-in-situ concrete light pipe column wallboard. The process and main points of the modeling are described taking cast-in-place concrete lightweight pipe column wallboard test LCCWB-1 as an example. LCCWB-1 consists of hidden beam, concealed column, wallboard, distributed reinforcement, beamcolumn longitudinal bearing force reinforcement, stirrup and lacing wire.

Considering that stirrup and lacing wire have little effect on the bearing capacity of wallboard, they are not considered in modeling process.LCCWB- 1 is a wallboard embedded with a hollow tube, so the interior of the wallboard needs to be hollowed during modeling. In the ABAQUS software, it is difficult to achieve hollowing inside a part. In this paper, the method is to first move the upper end of the wallboard down to the holed surface with a certain distance, and then draw the hole shape on this surface, and then start the cutting operation. In addition, considering that the unit is not regular and difficult to meet the requirement of convergence when dividing the mesh on the circular hole section, the hollow cylinder is transformed into a hollow square tube based on the principle of equal area and flexural rigidity (as shown in formula 5) [6].

$$
\left\{\begin{array}{l}
b_{1} h_{1}=\frac{\pi d^{2}}{4} \\
\frac{b_{1} h_{1}^{3}}{12}=\frac{\pi d^{4}}{64}
\end{array}\right.
$$

$b_{1}$ is the width of the transformed square tube. $h_{1}$ is the height of the transformed square tube $d$ is the diameter of hollow circular tube before transformation.

In this paper, the nonlinear force performance of cast-in-place concrete column wallboard under the action of axial load and lateral load is studied.

Therefore, in addition to the initial analysis step, there are two steps to be set up. The initial analysis step is mainly to define the boundary conditions of the wallboard. The first step is to apply the axial load to the wallboard. The second step is to apply the lateral load to the wallboard [7]. 


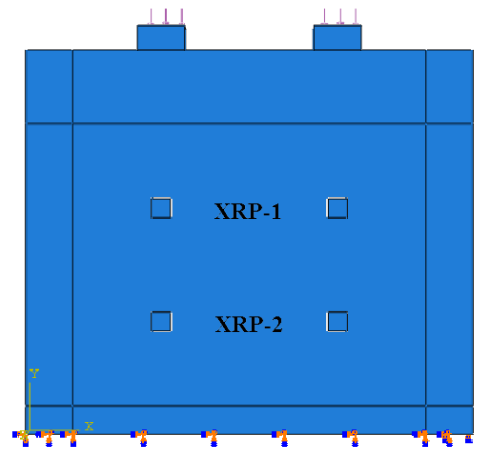

Figure 1. Applied load diagram

ABAQUS has a rich cell library, and a different cell library should be selected for different problems.

The linear complete integral unit and the second complete integral unit generally have no problem of shearing self-locking. However, in the elastoplastic analysis, there will be a certain degree of selflocking. The linear reduced integral unit uses one integration less than the complete integral unit in each direction. However, when the grid is distorted, the analysis accuracy will not be greatly affected.

Moreover, the shear locking phenomenon is not easy to occur under the action of bending load.

Although the secondary reduction integral unit is more accurate than the first reduction unit, it is prone to serious hourglass problems. Noncoordination unit overcomes the problem of shearing self-locking. However, when the cell distortion is large, the analysis accuracy decreases.

After much consideration, the concrete uses the space 8-node reduction unit and the bar adopts the rod unit simulation [8].

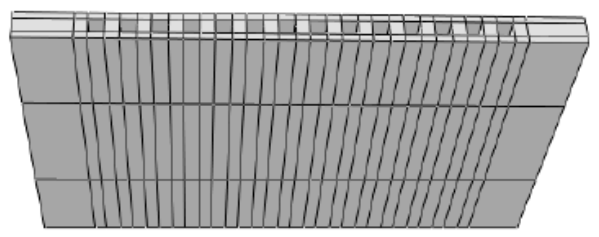

Figure 2. The divided cell component

\subsection{Comparison of nonlinear finite element analysis results of cast - in -situ concrete light pipe column wallboard}

From the comparison between the simulated values of load displacement curves of third and fourth points of LCCWB-0 LCCWB-7 specimens and the experimental values, it is found that the load displacement curves obtained by finite element simulation coincide with the load displacement curves obtained during the test without cracking stage. However, at the stage of fracture work, although the two trends are the same, the simulated load is much larger than the test value under the same level displacement.

At the end of the failure stage, the simulation value is basically consistent with the test value. The difference between the ultimate bearing capacity of the simulated specimen and the test value is within $10 \%$.

The effect of bond slip between the reinforced concrete and the concrete is not considered when the specimen is simulated at the stage of crack operation. However, in fact, after the cracking of concrete, the stiffness of the specimen is reduced to a certain extent because there is a certain slip between the steel and the concrete.

This reduction degree depends on the quality of the construction. The test piece with more concrete has a small reduction, and the test piece with less concrete has large reduction.

In the simulation, the effect of bond slip is not taken into account, so that the specimen stiffness is only corrected when the specimen is cracked. Moreover, the used concrete structure is not the data measured by the test. Therefore, the characteristics of the material cannot be truly reflected, which leads to a certain error between the simulated value and the test value [9].

The supported condition of other three sides of the specimen is: The trilateral support is placed on the steel roller with steel plate to form a simply supported edge. With the increase of load test, three simple supported edges of the specimen have a trend to rotate around the steel roller. The four angles of the specimen have a lifted edge. Therefore, the vertical displacement of the specimen increases. The reason why the simulated value is larger than the experimental value may be caused by the different boundary conditions [10].

During the test, the lateral is loaded on the specimen, and each load lasts $10 \mathrm{~min}$. Therefore, the development of cracks is more adequate.

When simulating the load, the load is applied once. The action time is relatively short and the development of cracks is not sufficient. Therefore, the specimen stiffness in the working stage with cracks is larger than that in the test stage.

Table 1: LCCWB-0 LCCWB-7 specimen capacity comparison

\begin{tabular}{|c|c|c|c|c|c|c|c|c|}
\hline LCCWB & 0 & 1 & 2 & 3 & 4 & 5 & 6 & 7 \\
\hline Test value (kN) & 580 & 520 & 500 & 440 & 460 & 530 & 560 & 430 \\
\hline Simulation value (kN) & 592 & 526 & 508 & 463 & 458 & 554 & 574 & 427 \\
\hline Error \% & 2.07 & 1.15 & 1.6 & 5.23 & 0.43 & 4.53 & 1.07 & 0.7 \\
\hline
\end{tabular}




\section{Nonlinear Analysis on Mechanical Behavior of Cast - in - situ Concrete Light Pipe Column Wallboard}

ABAQUS finite element analysis software is used to investigate the influence of the parameters such as volume hollow ratio, pipe length, load form, boundary condition and axial compression ratio on the bearing capacity of cast-in-situ concrete light pipe column wallboard.

\subsection{Effect of volume hollow ratio on the bearing capacity of cast-in-situ concrete light pipe column wallboard}

Under the condition that other parameters are not changed, the influence of the volume void ratio of wall board on the bearing capacity of cast-in-situ concrete light wallboard is studied. The size and reinforcement of the model are the same as those of the specimen, and the change of volume hollow ratio is shown in table 2 .

Table 2: Change of volume hollow ratio

\begin{tabular}{|c|c|c|c|c|c|}
\hline $\begin{array}{l}\text { Model } \\
\text { No. }\end{array}$ & $\begin{array}{l}\text { Volume hollow ratio } \\
\text { pc (\%) }\end{array}$ & Pipe length & Load form & $\begin{array}{l}\text { Boundary } \\
\text { condition }\end{array}$ & $\begin{array}{c}\text { Axial } \\
\text { compression ratio }\end{array}$ \\
\hline $\mathrm{m}-0$ & 0 & \multirow{6}{*}{$\begin{array}{c}\text { A row is } 1500 \\
\mathrm{~mm}\end{array}$} & \multirow{6}{*}{$\begin{array}{l}\text { Triangle } \\
\text { load }\end{array}$} & \multirow{6}{*}{$\begin{array}{l}\text { Three } \\
\text { simply } \\
\text { supported } \\
\text { and one } \\
\text { fixed edges }\end{array}$} & \multirow{6}{*}{$\begin{array}{l}\text { The axial } \\
\text { compression ratio } \\
\text { is } 0.5 \text { on the } \\
\text { concealed } \\
\text { column. }\end{array}$} \\
\hline$m-1$ & 4.5 & & & & \\
\hline$m-2$ & 8.0 & & & & \\
\hline$m-3$ & 11.4 & & & & \\
\hline$m-4$ & 16.0 & & & & \\
\hline$m-5$ & 19.4 & & & & \\
\hline
\end{tabular}

After the ABAQUS simulation, the change chart of the wallboard bearing capacity can be obtained when the volume hollow ratio is changed. As shown in table 3 , the larger the volume hollow ratio is, the smaller the wallboard's bearing capacity is. As shown in figure 3 , under the different volume hollow ratio, the trend of the load displacement curve of the wallboard is consistent. The cracking load of wallboard decreases with the increase of volume hollow ratio. Due to cross section opening-cell, the elastic resistance moment of section decreases, resulting in smaller cracking moment [11].

As shown in figure 4, when the volume hollow ratio is zero, the wallboard has no opening-cell.
The bearing capacity is the biggest at this time. When the volume hollow ratio is at $5 \% \sim 10 \%$, the bearing capacity decreases with the increase of volume hollow ratio. When the volume hollow ratio is greater than $10 \%$, the bearing capacity increases with the increase of volume hollow ratio. When the opening-cell is still small, the wallboard is bending failure when it reaches the limit load.

When the opening-cell is reached to a certain extent, the wallboard may appear shear or local shear failure when the ultimate load is reached. Because of the different forms of failure, the bearing capacity of the wallboard will vary with the volume hollow ratio.

Table 3: The change of the bearing capacity of the wallboard with different volume hollow ratio

\begin{tabular}{|c|c|c|}
\hline Model No. & Volume hollow ratio (\%) & Bearing capacity (kN) \\
\hline $\mathrm{m}-0$ & 0 & 558 \\
\hline $\mathrm{m}-1$ & 4.5 & 518 \\
\hline $\mathrm{m}-2$ & 8.0 & 510 \\
\hline $\mathrm{m}-3$ & 11.4 & 485 \\
\hline $\mathrm{m}-4$ & 16.0 & 449 \\
\hline $\mathrm{m}-5$ & 19.4 & 402 \\
\hline
\end{tabular}

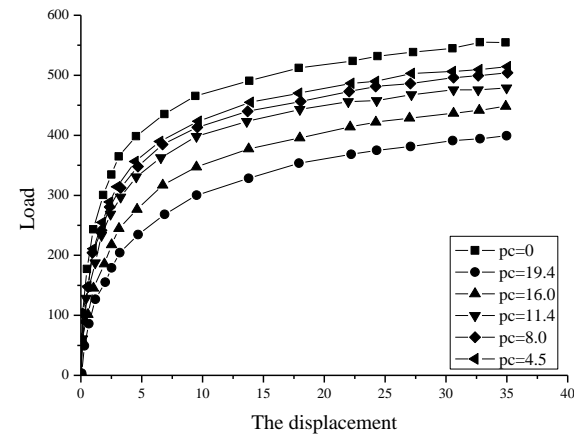

Figure 3. Load displacement curve of wallboard with different volume hollow ratio $\rho c$.

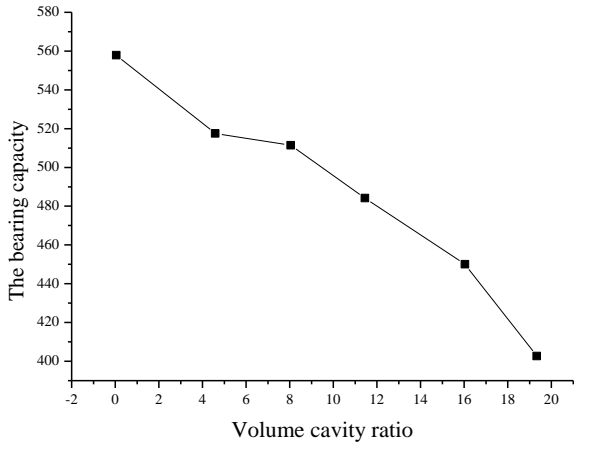

Figure 4. Bearing capacity curve of volume hollow ratiopc 
In practical engineering, when using cast-in-situ concrete light pipe column wallboard with different volume hollow rate, we should consider not only the influence of hydration heat but also the reduction of wallboard bearing capacity. At the same time, the economy of engineering construction should be taken into account. It should be rationally selected on the basis of comprehensive consideration of various factors. According to the simulation result, the volume hollow ratio of wallboard is recommended to be controlled within $0 \% \sim 10 \%$.

The wall panel with different volume hollow ratio is mainly realized by selecting different pipe diameter and rib width. The decrease of the pipe diameter and the increase of the rib width can improve the flexural performance and the integrity of cast-in-situ concrete light pipe column wallboard.

However, the small diameter and wide rib width can increase the bearing capacity of wallboard, but also increase the amount of concrete pouring.

Therefore, the purpose of reducing hydration heat of concrete is not achieved.

In practical engineering, when selecting pipe diameter and rib width, on the one hand, we must ensure that the section has enough bearing capacity, and on the other hand, we should achieve the purpose of reducing temperature stress.

It is suggested that the ratio of the pipe diameter to the thickness is $0.4 \sim 0.6$ [4] during the engineering design process. In actual construction, to prevent too small rib width, it is not convenient for concrete to vibrate and dense.

It is suggested that rib width should be greater than $100 \mathrm{~mm}$ in actual engineering, and the ratio of rib width to plate thickness is $0.25 \sim 0.5$.

\subsection{Influence of pipe length on the bearing capacity of cast-in-situ concrete light pipe column wallboard}

Under the condition that other parameters are not changed, the influence of the pipe length of the wallboard on the bearing capacity of the cast-in-situ concrete light pipe column wallboard is studied.

The size and reinforcement of the model are the same as those of the specimen, and the change of the pipe mode is shown in table 4.

\begin{tabular}{|c|c|c|c|c|c|c|}
\hline & & & & & & Table 4 Pipe length \\
\hline $\begin{array}{l}\text { Mode } \\
\text { No. }\end{array}$ & $\begin{array}{c}\text { Pipe } \\
\text { diameter } \\
(\mathrm{mm})\end{array}$ & $\begin{array}{c}\text { Rib } \\
\text { width } \\
(\mathrm{mm})\end{array}$ & $\begin{array}{l}\text { Pipe } \\
\text { length }\end{array}$ & Load form & $\begin{array}{l}\text { Boundary } \\
\text { condition }\end{array}$ & $\begin{array}{l}\text { Axial compression } \\
\text { ratio }\end{array}$ \\
\hline$m-4$ & 75 & 50 & $1500 \mathrm{~mm}$ & \multirow{3}{*}{$\begin{array}{l}\text { Triangle } \\
\text { load }\end{array}$} & \multirow{3}{*}{$\begin{array}{c}\text { Three simply } \\
\text { supported and } \\
\text { one fixed edges }\end{array}$} & \multirow{3}{*}{$\begin{array}{l}\text { The axial compression } \\
\text { ratio is } 0.5 \text { on the } \\
\text { concealed column. }\end{array}$} \\
\hline$m-6$ & & & $1000 \mathrm{~mm}$ & & & \\
\hline$m-7$ & & & $500 \mathrm{~mm}$ & & & \\
\hline
\end{tabular}

The calculation results of the ABAQUS are shown in table 5 and figure 5 . The pipe length has a certain influence on the bearing capacity of the wallboard. When $1500 \mathrm{~mm}$ PVC pipe and $1000 \mathrm{~mm}$ PVC pipe are arranged, the wallboard loading capacity of PVC pipe with the length $1000 \mathrm{~mm}$ is larger than that with the length of $1500 \mathrm{~mm}$ at the early stage of loading. However, at the later stage of loading, the bearing capacity of the two pipes is very close. However, when the PVC tube with the length of $500 \mathrm{~mm}$ is arranged, the loading capacity of the wallboard increases a lot, but the bearing capacity is still much lower than the wallboard that has no opening-cell [12].

Table 5 Change of bearing capacity of wallboard with different pipe length

\begin{tabular}{|c|c|c|}
\hline Model No. & Pipe length & $\begin{array}{c}\text { Bearing } \\
\text { capacity }(\mathrm{kN})\end{array}$ \\
\hline $\mathrm{m}-4$ & $1500 \mathrm{~mm}$ & 456 \\
\hline $\mathrm{m}-6$ & $1000 \mathrm{~mm}$ & 458 \\
\hline $\mathrm{m}-7$ & $500 \mathrm{~mm}$ & 498 \\
\hline
\end{tabular}

With the increase of the length of PVC tube, the weakening degree of the section increases and the bearing capacity of the wallboard decreases.

However, the increase of this weakening degree has a limited effect on the bearing capacity. That is, when the length of the PVC pipe increases to a certain amount, the bearing capacity of the wallboard will hardly change.

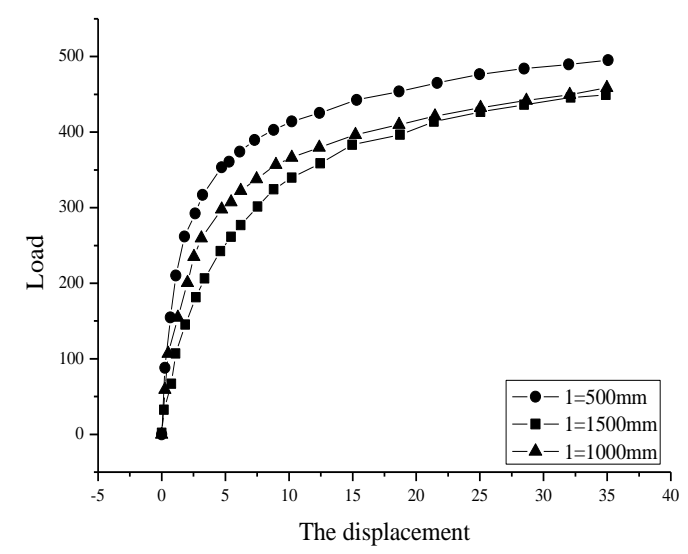

Figure 5 Load displacement curve of wallboard with different pipe length. 
This phenomenon shows that the cross section near the upper simply supported boundary does not play a role in the bearing capacity of the wallboard.

From the above analysis, when the PVC pipe is at $1000 \mathrm{~mm} 1500 \mathrm{~mm}$, the bearing capacity of the wallboard is almost not affected by the length of PVC pipe. To effectively reduce the influence of hydration heat of concrete, a longer PVC pipe can be selected, and the bearing capacity of the wallboard will not be affected.

\subsection{Effect of load form on the bearing capacity of cast-in-situ concrete light pipe column wallboard}

Under the condition that other parameters remain unchanged, the influence of the load form on the bearing capacity of the cast-in-situ concrete light pipe column wallboard is studied by changing the load form. The size and reinforcement of the model are the same as those of the specimen, and the change of the load form is shown in table 6.

\begin{tabular}{|c|c|c|c|c|c|c|}
\hline $\begin{array}{c}\text { Model } \\
\text { No. }\end{array}$ & $\begin{array}{c}\text { Pipe diameter } \\
(\mathrm{mm})\end{array}$ & $\begin{array}{c}\text { Rib width } \\
(\mathrm{mm})\end{array}$ & Pipe length & Load form & $\begin{array}{c}\text { Boundary } \\
\text { condition }\end{array}$ & $\begin{array}{c}\text { Axial compression form } \\
\text { ratio }\end{array}$ \\
\cline { 1 - 4 } $\mathrm{m}-4$ & 75 & 50 & $\begin{array}{c}\text { A row is } \\
1500 \mathrm{~mm}\end{array}$ & $\begin{array}{c}\text { Triangle } \\
\text { load }\end{array}$ & $\begin{array}{c}\text { Three simply } \\
\text { supported } \\
\text { and one fixed } \\
\text { edges }\end{array}$ & $\begin{array}{c}\text { The axial } \\
\text { compression ratio is } \\
0.5 \text { on the concealed } \\
\text { column. }\end{array}$ \\
\hline
\end{tabular}

The calculation results of the ABAQUS are shown in table 7 and figure 6 . It is found that the load distribution has an obvious influence on the bearing capacity of the cast-in-situ concrete light pipe column wallboard. Under the effect of triangular load, the bearing capacity of the wallboard is much larger than the uniform load effect. Therefore, the joint force acting on the load is located below the middle span, which is beneficial to the improvement of the bearing capacity of the wall board. When the cast-in-situ concrete light pipe column wallboard is applied to the exterior wall of basement, it will bear the lateral action of earth pressure, water pressure and ground live load. Then the form of the load may be trapezoid. The trapezoidal loading can be obtained by superimposing the triangle load and the uniform load. It is concluded that when the wallboard is subjected to trapezoid loading, its carrying capacity will be between the load capacity of the wallboard under the triangular load and the load capacity of the wallboard under uniform load.

Table 7 Change of load-bearing capacity of wallboard with different load forms

\begin{tabular}{|c|c|c|}
\hline $\begin{array}{c}\text { Model } \\
\text { No. }\end{array}$ & Load form & $\begin{array}{c}\text { Bearing } \\
\text { capacity }(\mathrm{kN})\end{array}$ \\
\hline $\mathrm{m}-4$ & Triangular load & 456 \\
\cline { 1 - 1 } $\mathrm{m}-8$ & Uniform load & 320 \\
\hline
\end{tabular}

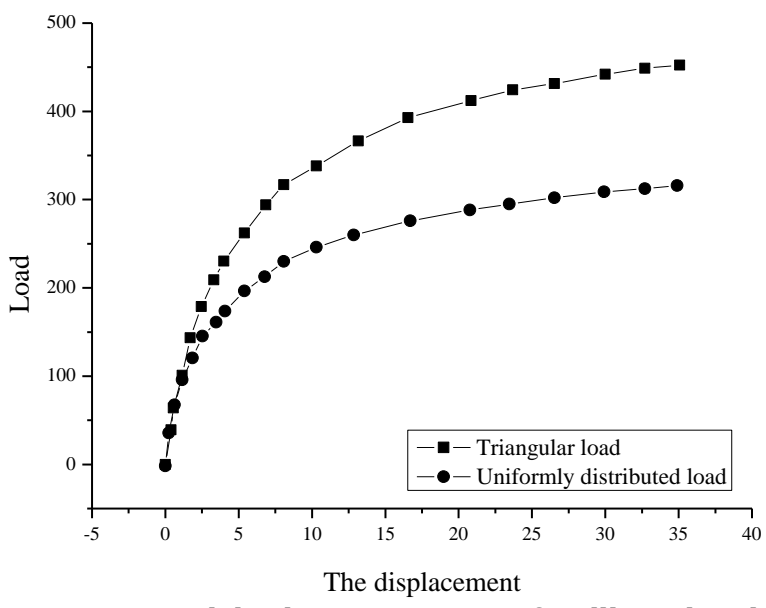

Figure 6 Load displacement curve of wallboard with different load form

\subsection{Effect of boundary conditions on the bearing capacity of cast-in-situ concrete light pipe column wallboard}

Under the condition that other parameters remain unchanged, the effect of the boundary conditions on the bearing capacity of the cast-in-situ concrete light pipe column wallboard is studied by changing the boundary conditions.

The size and reinforcement of the model are the same as those of the specimen, and the change of the boundary conditions is shown in table 8 .

Table 8 Boundary condition

\begin{tabular}{|c|c|c|c|c|c|c|}
\hline $\begin{array}{c}\text { Model } \\
\text { No. }\end{array}$ & $\begin{array}{c}\text { Pipe diameter } \\
(\mathrm{mm})\end{array}$ & $\begin{array}{c}\text { Rib width } \\
(\mathrm{mm})\end{array}$ & $\begin{array}{c}\text { Pipe } \\
\text { length }\end{array}$ & $\begin{array}{c}\text { Load } \\
\text { form }\end{array}$ & $\begin{array}{c}\text { Boundary } \\
\text { condition }\end{array}$ & $\begin{array}{c}\text { Axial compression } \\
\text { ratio }\end{array}$ \\
\hline $\mathrm{m}-4$ & 75 & 50 & $\begin{array}{c}\text { A row is } \\
1500 \mathrm{~mm}\end{array}$ & $\begin{array}{c}\text { Triangle } \\
\text { load }\end{array}$ & $\begin{array}{c}\text { Three simply } \\
\text { supported and } \\
\text { one fixed edges }\end{array}$ & $\begin{array}{c}\text { The axial } \\
\text { compression ratio is } \\
0.5 \text { on the concealed } \\
\text { column. }\end{array}$ \\
\hline
\end{tabular}


The calculation results of the ABAQUS are shown in table 9 and figure 7 . Table 9 shows that the boundary conditions have a great influence on the bearing capacity of the wallboard. The closer the boundary is to the fixed support, the greater its bearing capacity is. The closer the boundary is to the fixed support, the greater the load that needs to be exerted is before the component becomes a mechanism and damage.

Table 9 Change of bearing capacity of wallboard with different boundary conditions

\begin{tabular}{|c|c|c|}
\hline $\begin{array}{c}\text { Model } \\
\text { No. }\end{array}$ & Boundary condition & $\begin{array}{c}\text { Bearing } \\
\text { capacity (kN) }\end{array}$ \\
\hline $\mathrm{m}-4$ & $\begin{array}{c}\text { Three simply } \\
\text { supported and one } \\
\text { fixed edges }\end{array}$ & 456 \\
\hline $\mathrm{m}-9$ & $\begin{array}{c}\text { Opposite edges simply } \\
\text { supported and other } \\
\text { two edges fixed }\end{array}$ & 674 \\
\hline $\mathrm{m}-10$ & Four fixed edges & 876 \\
\hline
\end{tabular}

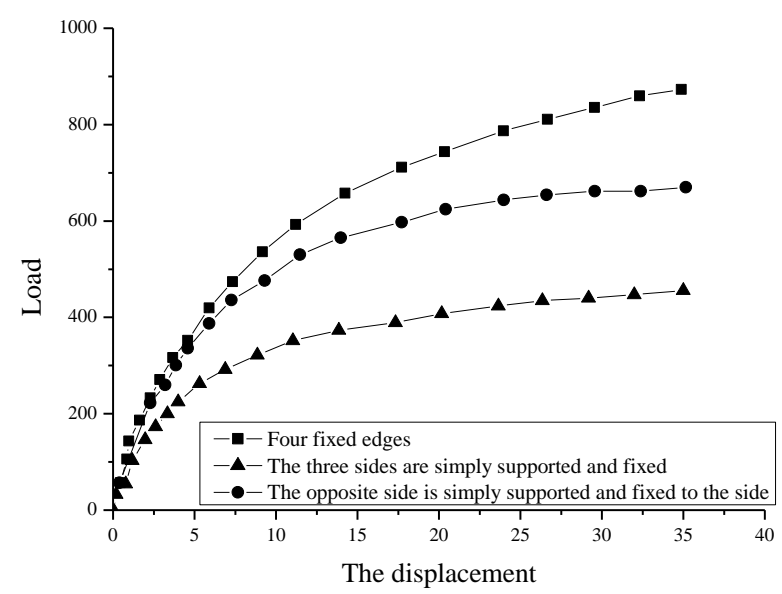

Figure 7 Load displacement curve of wallboard with different boundary conditions.
In the actual design process, the different boundary conditions can be achieved by changing the stiffness ratio of hidden beam and concealed column to the wallboard. When the wallboard stiffness is constant, the stiffness ratio is larger when the stiffness of beam and column increases. At this point, the closer the boundary is to the fixed support, the greater the negative bending moment at the boundary is. When the stiffness ratio is close, the hidden beam and concealed column can be regarded as the reinforcing band on the wallboard and can be considered according to the elastic support.

However, at this time, a large positive bending moment is assumed in the mid span, which is not conducive to the improvement of the bearing capacity of the wallboard. However, if we want to increase the stiffness of beam and column, it is bound to rely on increasing beam or column section or improving the reinforcement to achieve it. This undoubtedly increases the quantity of the project and the cost of the project.

Therefore, how to ensure the bearing capacity without significantly increasing the amount of work is an issue that needs to be considered in a comprehensive way.

\subsection{Effect of axial compression ratio and its location on the bearing capacity of cast - in - situ concrete light pipe column wallboard}

Under the condition that other parameters remain unchanged, the influence of the axial compression ratio and its action location on the bearing capacity of cast-in-situ concrete light pipe column wallboard is studied.

The size and reinforcement of the model are the same as the specimen, and the axial compression ratio and the change of its action position are shown in table 10 .

Table 10 Change of axial compression ratio

\begin{tabular}{|c|c|c|c|c|c|c|c|}
\hline $\begin{array}{l}\text { Model } \\
\text { No. }\end{array}$ & $\begin{array}{c}\text { Pipe } \\
\text { diameter } \\
(\mathrm{mm})\end{array}$ & $\begin{array}{l}\text { Rib width } \\
\text { (mm) }\end{array}$ & $\begin{array}{l}\text { Pipe } \\
\text { length }\end{array}$ & $\begin{array}{l}\text { Load } \\
\text { form }\end{array}$ & $\begin{array}{l}\text { Boundary } \\
\text { condition }\end{array}$ & $\begin{array}{l}\text { Axial force } \\
\text { position }\end{array}$ & $\begin{array}{c}\text { Axial } \\
\text { compressio } \\
\text { n ratio } \\
\end{array}$ \\
\hline $\mathrm{Z}-1$ & \multirow{5}{*}{75} & \multirow{5}{*}{50} & \multirow{5}{*}{ A row } & \multirow{5}{*}{$\begin{array}{l}\text { Triangle } \\
\text { load }\end{array}$} & \multirow{5}{*}{$\begin{array}{c}\text { Three } \\
\text { simply } \\
\text { supported } \\
\text { and one } \\
\text { fixed edges }\end{array}$} & \multirow{5}{*}{$\begin{array}{l}\text { Concealed } \\
\text { column }\end{array}$} & 0.2 \\
\hline $\mathrm{Z}-2$ & & & & & & & 0.3 \\
\hline $\mathrm{Z}-3$ & & & & & & & 0.4 \\
\hline $\mathrm{Z}-4$ & & & & & & & 0.5 \\
\hline $\mathrm{Z}-5$ & & & & & & & 0.6 \\
\hline$Q-1$ & \multirow{5}{*}{75} & \multirow{5}{*}{50} & \multirow{5}{*}{ A row } & \multirow{5}{*}{$\begin{array}{c}\text { Triangle } \\
\text { load }\end{array}$} & \multirow{5}{*}{$\begin{array}{c}\text { Three } \\
\text { simply } \\
\text { supported } \\
\text { and one } \\
\text { fixed edges }\end{array}$} & \multirow{5}{*}{$\begin{array}{l}\text { Concealed } \\
\text { column }\end{array}$} & 0.2 \\
\hline$Q-2$ & & & & & & & 0.3 \\
\hline Q-3 & & & & & & & 0.4 \\
\hline Q-4 & & & & & & & 0.5 \\
\hline$Q-5$ & & & & & & & \\
\hline
\end{tabular}

The calculation results of the ABAQUS are shown in table 11, figure 8 and figure 9. Whether the axial force is applied to concealed column or wallboard, the bearing capacity of wallboard increases with the increase of axial compression ratio, but the axial compression ratio has little influence on the bearing capacity of wallboard. The application of axial pressure is equivalent to the application of prestress 
to the wallboard, which postpones the development time of the crack. However, because the axial pressure is very small, it cannot achieve the effect of applying the prestress process.

Therefore, the bearing capacity of the wallboard can only be increased by a small portion.

As shown in figure 10, the axial compression ratio is almost linear with the bearing capacity.
When the axial pressure acting on the wallboard, the increase speed of bearing capacity varying with the axial compression ratio is faster than acting on the column. This shows that the effect of axial pressure on the bearing capacity of the wallboard is less than the concealed column.

When the axial pressure acting on the wallboard, the wallboard has great influence on bearing capacity.

Table 11 Axial compression ratio and wallboard bearing capacity change acting on different positions

\begin{tabular}{|c|c|c|c|}
\hline Model No. & $\begin{array}{l}\text { Axial force acting } \\
\text { position }\end{array}$ & Axial compression ratio & $\begin{array}{l}\text { Bearing capacity } \\
(\mathrm{kN})\end{array}$ \\
\hline $\mathrm{Z}-1$ & \multirow[t]{5}{*}{ Concealed column } & 0.2 & 413 \\
\hline $\mathrm{Z}-2$ & & 0.3 & 425 \\
\hline $\mathrm{Z}-3$ & & 0.4 & 437 \\
\hline Z-4 & & 0.5 & 448 \\
\hline $\mathrm{Z}-5$ & & 0.6 & 458 \\
\hline$Q-1$ & \multirow[t]{5}{*}{ Concealed column } & 0.2 & 420 \\
\hline$Q-2$ & & 0.3 & 436 \\
\hline$Q-3$ & & 0.4 & 451 \\
\hline$Q-4$ & & 0.5 & 467 \\
\hline$Q-5$ & & 0.6 & 481 \\
\hline
\end{tabular}

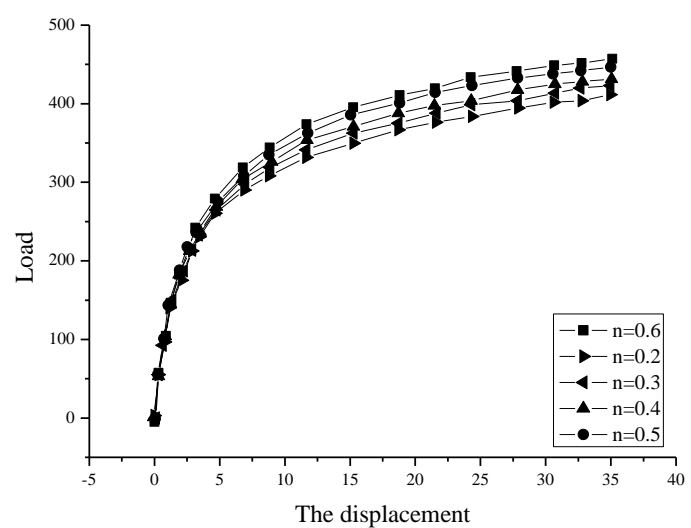

Figure 8 Load - displacement curve of wallboard with different axial compression ratio $n$ (axial pressure acts on the concealed column)

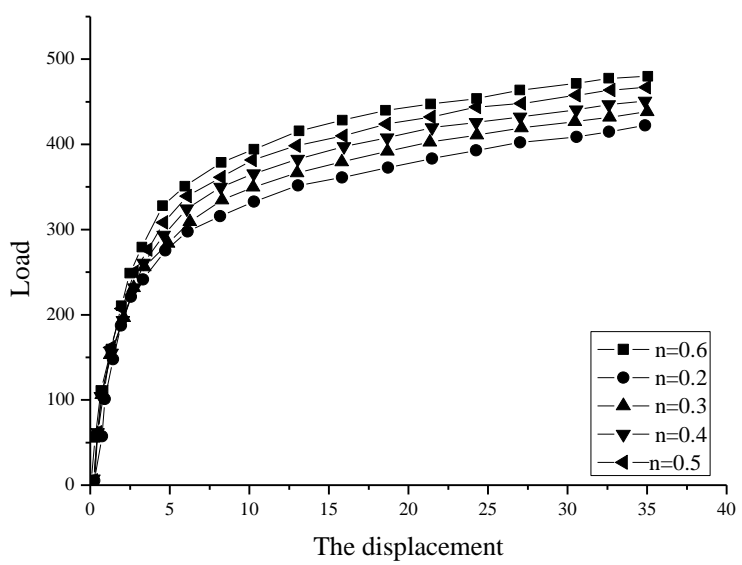

Figure 9 Load - displacement curve of wallboard with different axial compression ratio $n$ (axial pressure acts on the wallboard)

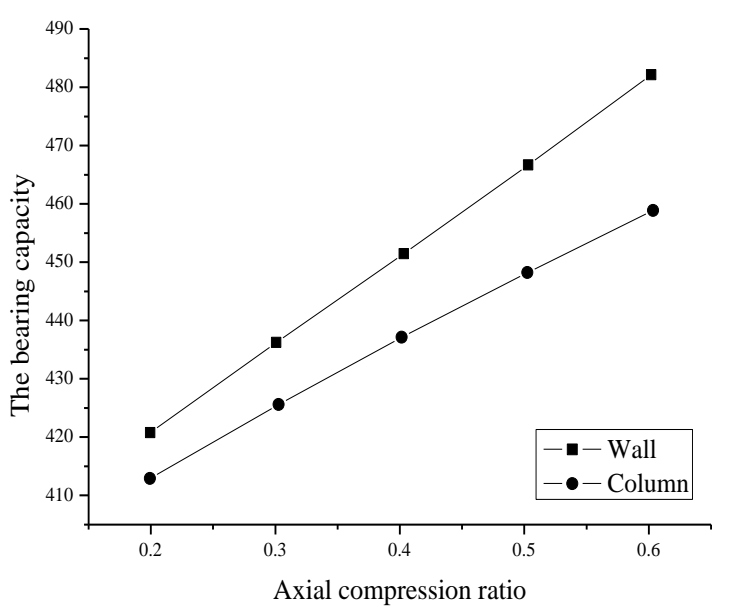

Figure 10 Axial compression ratio n-bearing capacity curve

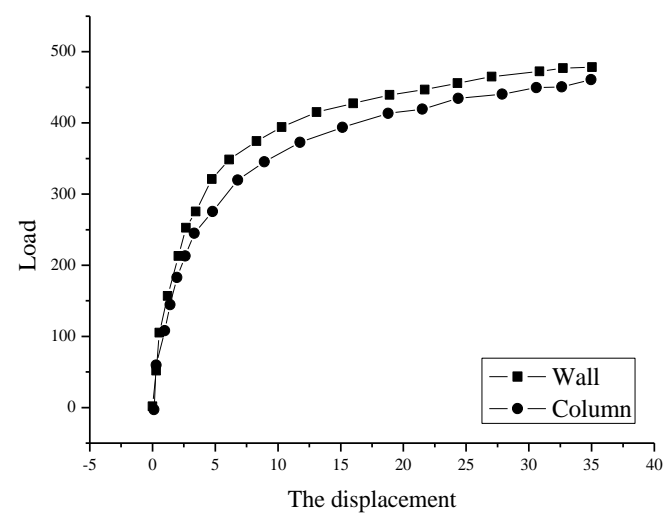

Figure 11 The effect of different position on the bearing capacity when the axial pressure ratio is $n=0.6$ 
As shown in figure 11, for the same axial compression ratio, when the axial pressure acts on the wallboard, the bearing capacity of the wallboard is greater than when the axial pressure acts on the concealed column. It is shown that applying axial pressure on the wallboard can inhibit the wallboard crack and improve the bearing capacity.

In practical engineering, the axial compression ratio should not be too small because it cannot effectively play the bearing capacity of the wallboard, but also uneconomic. But the axial pressure ratio should not be too large. The large pressure affects the structure safety and it should be within $0.4 \sim 0.6$.

\section{Conclusion}

The ABAQUS software is used to analyze the influence of pipe length on the bearing capacity of cast-in-situ concrete light pipe column wallboard.

The calculation result shows that the loading capacity of PVC pipe with the length of $1500 \mathrm{~mm}$ is close to one with the length of $1000 \mathrm{~mm}$. However, when placing PVC pipe with the length of $500 \mathrm{~mm}$, the bearing capacity of the wallboard is much improved. When the length of PVC pipe is between $1000 \mathrm{~mm}$ and $1500 \mathrm{~mm}$, the bearing capacity of the wallboard is hardly affected by the length of the PVC pipe.

To effectively reduce the influence of hydration heat of the concrete, the PVC pipe with a longer length can be selected. The ABAQUS Software is used to analyze the influence of load form on the bearing capacity of

The calculation result shows that the bearing capacity of the wallboard under triangular load is much larger than the bearing capacity of the wallboard under the uniform load. The ABAQUS software is used to analyze the influence of boundary conditions on the bearing capacity of castin-situ concrete light pipe column wallboard. The calculation result shows that the boundary conditions have a great influence on the bearing capacity of the wallboard. The closer the boundary is to the fixed support, the greater its carrying capacity is. In the actual design process, different boundary conditions can be achieved by changing the stiffness ratio of hidden beam, concealed column to wallboard.

The ABAQUS software is used to analyze the influence of axial compression ratio and its location on the bearing capacity of cast-in-situ concrete light pipe column wallboard. The calculation result shows that the bearing capacity of the wallboard increases with the axial compression ratio, but the axial compression ratio has little effect on the bearing capacity of the wallboard.

For the same axial compression ratio, when the axial pressure acts on the wallboard, the bearing capacity of the wallboard is greater than when the axial pressure acts on the concealed column.

\section{Acknowledgement}

Jiangxi Provincial Education Hall 2017 science and technology key project: "technology and Experiment Research on hollow beam floor of assembly building

\section{References}

[1] Shang, R., \& Jiang, F. (2015). Experimental study on shear capacity of cast-in-situ concrete hollow floor in transverse direction. Jianzhu Jiegou Xuebao/journal of Building Structures, 36(5), 110-115.

[2] Valivonis, J., Popov, V., Jonaitis, B., \& Daugevičius, M. (2015). The analysis of concreting process impacts on the behaviour of residual liners of cast-in-situ voided slabs. Archives of Civil \& Mechanical Engineering, 15(4), 997-1006.

[3] Costa, R., Providência, P., \& Dias, A. (2016). Component based reinforced concrete beamcolumn joint model. Structural Concrete, 18(1), 164-176.

[4] Chen, S., \& Egger, P. (2015). Three dimensional elasto-viscoplastic finite element analysis of reinforced rock masses and its application. International Journal for Numerical \& Analytical Methods in Geomechanics, 23(1), 61-78.

[5] Lu, K., Accorsi, M., \& Leonard, J. (2015). Finite element analysis of membrane wrinkling. International Journal for Numerical Methods in Engineering, 50(5), 1017-1038.

[6] Kim, C. S., Lee, H. J., Park, C. K., Hwang, H. J., \& Park, H. G. (2016). Cyclic loading test for concrete-filled hollow precast concrete columns produced by using a new fabrication method. Journal of Structural Engineering, 143(4), 04016212.

[7] Radovitzky, R., \& Ortiz, M. (2015). Lagrangian finite element analysis of newtonian fluid flows. International Journal for Numerical Methods in Engineering, 43(4), 607-619.

[8] Jeong, J. H., \& Yang, D. Y. (2015). Finite element analysis of transient fluid flow with free surface using vof (volume-of-fluid) method and adaptive grid. International Journal for Numerical Methods in Fluids, 26(10), 1127-1154. 
[9] Mahn, J., \& Höller, C. (2017). The prediction of the flanking transmission in constructions of hollow concrete block masonry walls connected to precast prestressed concrete hollow core floors. Journal of the Acoustical Society of America, 141(5), 3479-3479.

[10] Majumdar, P., Jayaramachandran, R., \& Ganesan, S. (2015). Finite element analysis of temperature rise in metal cutting processes. Applied Thermal Engineering, 25(14), 21522168.
[11] HaoYu, Jung, D. W., YaZhang, Yoon, D. H., \& Kim, D. H. (2015). A study on finite element analysis of stamping process. Proceedings of the National Academy of Sciences of the United States of America, 99(2), 815-820.

[12] Yao, C., Liu, H., Zhao, Y., Mi, Y., Dong, S., \& Lv, Y. (2017). Analysis of dynamic processes in singlecell electroporation and their effects on parameter selection based on the finite-element model. IEEE Transactions.

\section{INCDMTM INNOVATIVE PRODUCTS:}

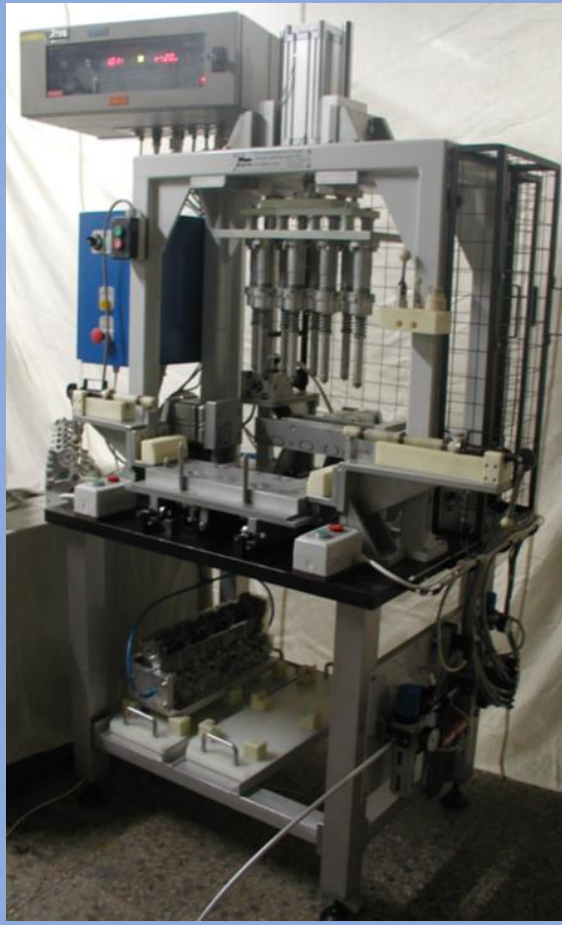

